\title{
Corneal bee sting in an HIV patient with a single functional eye. A case report
}

\section{Lesión corneal por picadura de abeja en paciente con VIH y ojo único funcional. Reporte de un caso}

\author{
Jossefat A. Godina-Morales*, Efraín Romo-García, Karen A. García-Medina, and \\ Alejandro Ruelas-Barreras \\ Ophthalmology Service, Hospital Civil de Culiacán, Center for Research and Teaching of Health Sciences, Culiacan, Sinaloa, Mexico
}

\begin{abstract}
Purpose: Bee stings cause different reactions in the eye, so each treatment must be individualized. Case report: $A$ 45-yearold male patient, HIV positive, one-eyed due to a right ocular trauma, suffered a corneal bee sting on the left eye. We performed surgery to extract the stinger and anterior chamber washout, since the patient did not improve after conservative treatment. Conclusions: Bee stings in ophthalmology are uncommon, and due to the previous clinical situation of the patient, it was important to decide the best treatment for him. The clinical response after a bee sting is very variable between patients, so it is a challenge for the ophthalmologist. Our surgical approach was very effective in this case, since the patient showed a visual recovery without relapse 7 months after the injury.
\end{abstract}

Key words: Bee. Cornea. Monocular. Bee Venom. HIV.

\section{Resumen}

Objetivo: Las picaduras de abeja resultan en distintas reacciones oftalmológicas, y por eso se debe individualizar el tratamiento en cada caso, dependiendo de su presentación clínica. Caso clínico: Varón de 45 años, portador del virus de la inmunodeficiencia humana y con ojo único por trauma ocular derecho, que acude a revisión por picadura de abeja 24 horas antes en el ojo izquierdo. Fue necesario realizar lavado de cámara anterior para la extracción del aguijón, ya que no se presentó mejoría clínica tras el manejo conservador. Conclusiones: Las picaduras de himenópteros en oftalmología son poco documentadas, y aunado a las características clínicas previas del paciente, fue importante decidir el tratamiento más conveniente. La respuesta clínica desencadenada por la picadura de abejas en los ojos es muy variable entre personas, por lo que constituye un reto para el oftalmólogo. La intervención quirúrgica demostró ser muy útil para la recuperación visual en este caso, la cual se mantiene hasta 7 meses después.

Palabras clave: Abeja. Córnea. Monocular. Veneno de abeja. VIH.

Correspondence:

*Jossefat A. Godina-Morales

Álvaro Obregón, 1422

Tierra Blanca

C.P. 80030 , Culiacan Rosales, Sin., Mexico

E-mail: Jagm1613@ hotmail.es

2604-1731/๑ 2020 Sociedad Mexicana de Oftalmología. Published by Permanyer. This is an open access article under the CC BY-NC-ND license (http://creativecommons.org/licenses/by-nc-nd/4.0/).
Date of reception: 20-02-2020

DOI: 10.24875/RMOE.M21000168

Available online: $21-05-2021$

Rev Mex Oftalmol (Eng). 2021;95(3):122-125

www.rmo.com.mx
Date of acceptance: $12-06-2020$ 


\section{Introduction}

Intraocular foreign bodies are common in ophthalmology, generally due to trauma, but the incidence of ocular wounds secondary to bee stings is less common. Bee stings can affect locally or induce a systemic response that can involve other eyeball structures, relatively distant from the site of the injury. The response can be mild, moderate or severe, in addition to carrying an infectious risk'. There is little evidence in ophthalmology on how these cases and their complications should be treated.

\section{Clinical case}

This is a 45-year-old man with human immunodeficiency virus (HIV) infection, who has been receiving efavirenz $600 \mathrm{mg}$, emtricitabine $200 \mathrm{mg}$ and tenofovir $300 \mathrm{mg}$ (Atripla ${ }^{\circledR}$ ), once every 24 hours for 10 years. He refers that his last viral load was undetectable and a CD4 count of 329 cells $/ \mathrm{mm}^{3}$ two months ago. He has a single eye due to an unspecified optic nerve injury secondary to right eye trauma in a car accident 20 years ago. He went to the Culiacan Civil Hospital for consultation with a 24-hour evolution of a bee sting in his left eye. Upon arrival, he reported pain, low vision, and a foreign body sensation in his left eye. Physical examination revealed the right eye with an areflexic pupil, clear cornea, formed anterior chamber, normal iris, transparent lens, applied retina with healthy vessels and a pale and atrophic optic nerve; the left eye showed conjunctival hyperemia $(+++)$, opaque and edematous cornea, with a whitish lesion in the second meridian that stains with fluorescein, striae in Descemet's membrane and cells in the anterior chamber (++), the lens with LOCS III NO2 NC2 and eye fundus not evaluable due to media opacities. Intraocular pressure (IOP) was $10 \mathrm{mmHg}$. Visual acuity: right eye no light perception, left eye 20/60 that does not improve with pinhole (Figs. 1 and 2).

We started treatment with ciprofloxacin $0.3 \%$ every 6 hours, preservative-free sodium hyaluronate $0.15 \%$ every 2 hours, tropicamide/phenylephrine ( $8 \mathrm{mg} / 50 \mathrm{mg} / \mathrm{mL}$ ) as a cycloplegic every 8 hours, prednisolone $1 \%$ every 4 hours and loratadine $10 \mathrm{mg}$ orally every 12 hours.

The patient is evaluated at the outpatient clinic 72 hours later observing a slight decrease of corneal opacity and edema, visualizing the corneal lesion in M2 with a predominantly inferior opacity, striae in Descemet's membrane, IOP of $10 \mathrm{mmHg}$ and iris with sectorial atrophy in $\mathrm{M} 2$, being able to observe a stinger on the

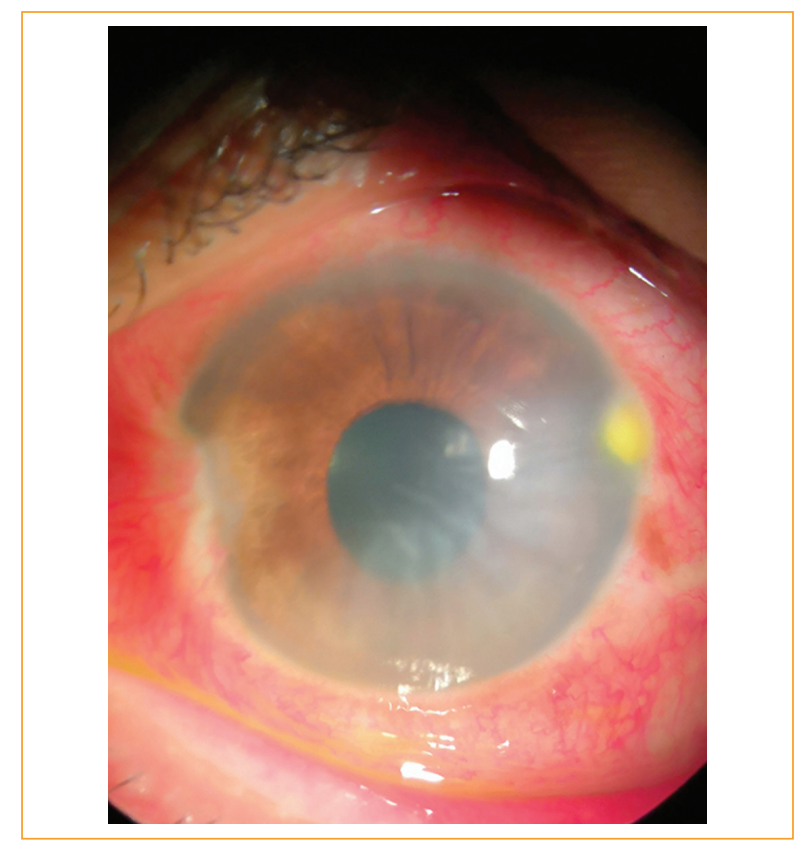

Figure 1. Initial photograph of the anterior segment showing conjunctival hyperemia with temporal and inferior corneal edema, as well as a lesion in the second meridian corresponding to the site of the sting.

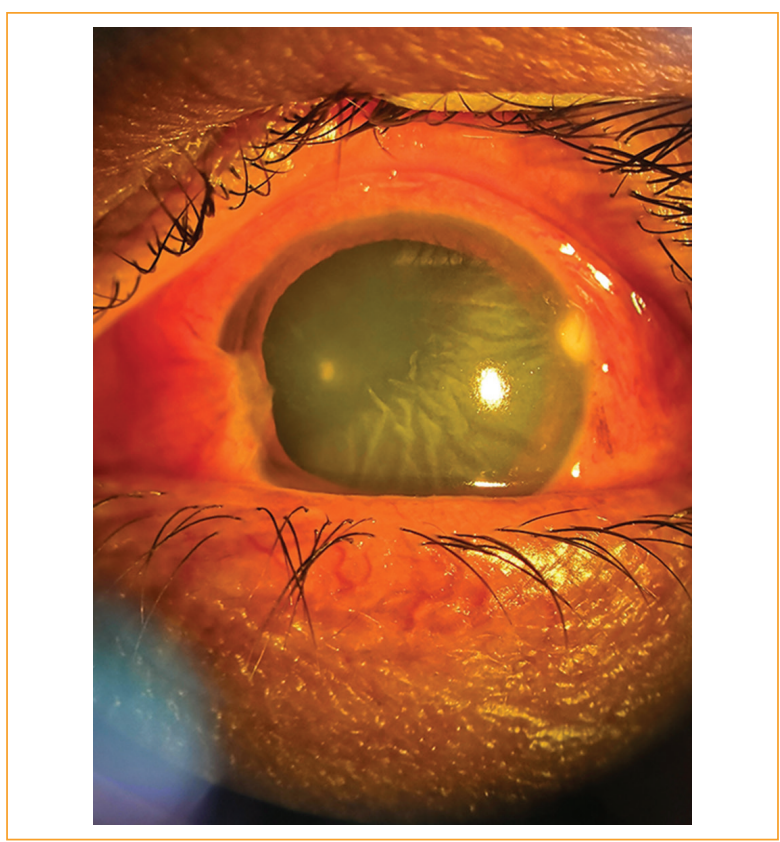

Figure 2. Photograph of the anterior segment with a dilated pupil, without apparent involvement of the lens.

iris (Fig. 3). The fundus was not evaluable due to media opacity. The visual acuity was of 20/50 in the left eye and did not improve, so 24 hours later it was decided 


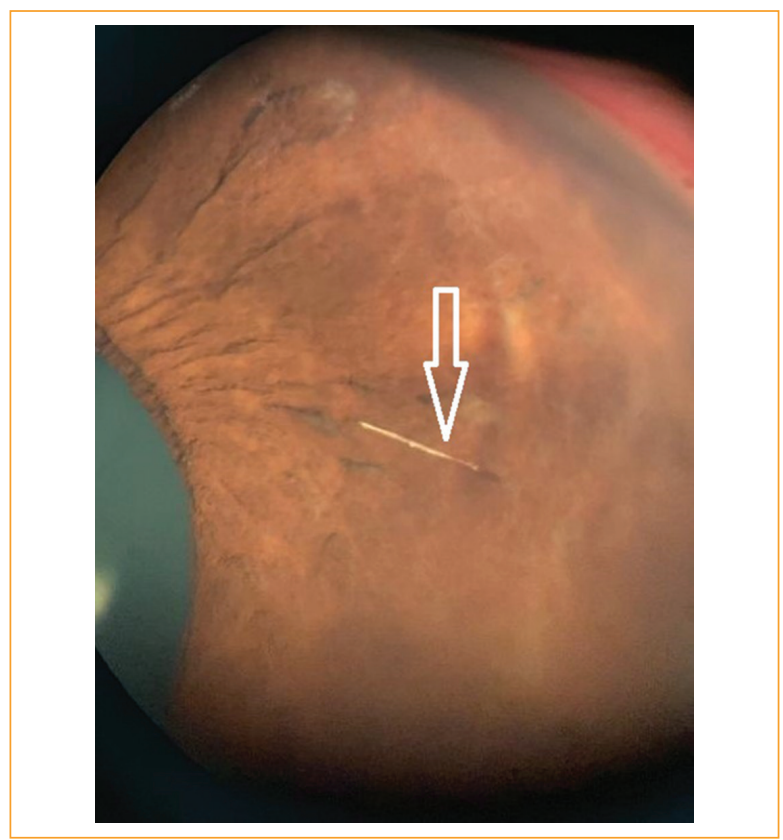

Figure 3. Bee stinger on the iris.

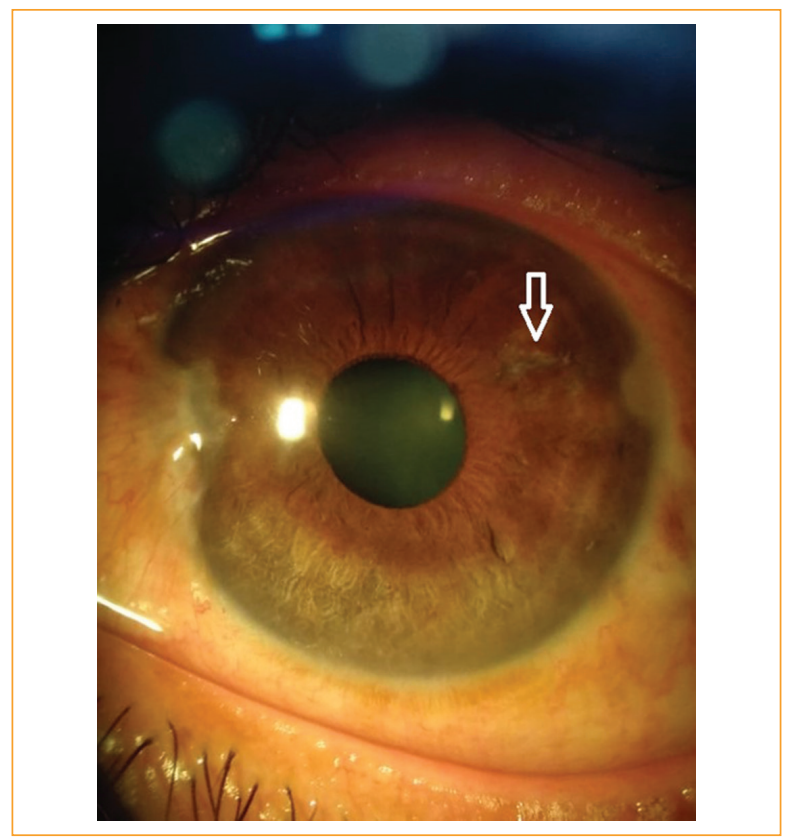

Figure 4. Photograph of the anterior segment 24 hours postoperatively, observing slight iris atrophy in the second meridian, where the stinger was.

to perform an anterior chamber washout and foreign body extraction.

The stinger was extracted after making a corneal incision with a $2.8 \mathrm{~mm}$ knife in M2. The chamber was formed with dispersive viscoelastic and the stinger fragment located in the iris stroma was removed using the Utrata forceps. Subsequently, the anterior chamber was irrigated with balanced saline solution and the edges of the corneal incision were hydrated, completing the procedure. The extracted sting was not cultured. Twenty-four hours after surgery, the patient showed symptoms improvement with a visual acuity of 20/20, normal pupil reflexes, hyperemic bulbar conjunctiva, clear cornea, wide and formed anterior chamber, intact iris, central pupil, IOP of $10 \mathrm{mmHg}$, applied retina, normal macula and a disc excavation of 4/10 (Fig. 4).

\section{Discussion}

It is controversial to decide treatment in patients with bee stings in the eyes, especially when there is retention of the stinger, since it has been shown that the permanence of the venom triggers reactions such as keratoconjunctivitis, endothelial degeneration, hypopyon, glaucoma, cataract, uveitis, vitritis or retinitis'. Furthermore, the stinger itself is an organic body of animal origin that could cause local infection ${ }^{2}$. In the case of our patient, the inflammatory and immune reaction seems to be in accordance with that described in the literature, without any significant change due to the previous immune status, although if the surgical procedure had not been performed, the complications in the patient might have increased given his immunosuppression.

The immune response triggered in this type of lesion induces the release of polypeptide toxins, such as phospholipase, hyaluronidase, melittin and apamine, as well as mediators such as histamine and dopamine, and begins minutes after the bite. Melittin is believed to participate in the formation of cataracts, while apamine has been proposed as a cause of optic neuropathy due to its neurotoxic properties ${ }^{2,3}$. Our patient sought consultation due to visual loss and pain secondary to stromal edema and keratitis, symptoms that were partially controlled with eye drops, but given the presence of the stinger in the anterior chamber, the HIV infection and having a single functional eye, we decided to remove the stinger to avoid complications. After removal, the patient had a notable improvement in visual acuity that has been maintained 7 months later. Fortunately, there was no reaction in the posterior segment of the eye, which helped him to have a rapid visual acuity recovery after surgery.

Rai, et al. ${ }^{2}$ suggest immediately removing the stinger if it is easily accessible and if there is a primary reaction 
involving the visual axis, even considering that surgical removal of the stinger is not always successful, given the complexity of its size and shape, while patients who do not meet these characteristics can be treated conservatively.

The local literature reports cases with watchful waiting based on steroid, antibiotic and cycloplegic eye drops with a good outcome, but with continuous monitoring to promptly detect any complication ${ }^{4}$. It is important to undertake a complete ophthalmological examination in these patients, including eversion of both eyelids to detect retained remains in the fornix that may cause long-term complications ${ }^{5}$.

\section{Conclusions}

Hymenoptera stings are rare cases in ophthalmology, but it is very important to decide the best treatment for the patient, since the clinical presentation can vary greatly on an individual basis. The decision to remove or not the stinger must be individualized in each case, given the idiosyncrasy. In our case there were more possible complications with conservative treatment. Surgical intervention was successful, achieving a visual acuity improvement maintained for up to 7 months after the event.

\section{Conflicts of interest}

The authors declare no conflicts of interest.

\section{Ethical disclosures}

Protection of human and animal subjects. The authors declare that no experiments were performed on humans or animals for this study.

Confidentiality of data. The authors declare that they have followed the protocols of their work center on the publication of patient data.

Right to privacy and informed consent. The authors have obtained the written informed consent of the patients or subjects mentioned in the article. The corresponding author is in possession of this document.

\section{References}

1. Ekta Rishi PR. Intraocular inflammation in a case of bee sting injury. GMS Ophthalmol. 2018;8:1-5.

2. Rai RR, Gonzalez-Gonzalez LA, Papakostas TD, Siracuse-Lee D, Dunphy R, Fanciullo L, et al. Management of corneal bee sting injuries. Semin Ophthalmol. 2017;32:177-81.

3. Semler-Collery A, Hayek G, Ramadier S, Perone JM. A case of conjunctival bee sting injury with review of the literature on ocular bee stings. Am J Case Rep. 2019;20:1284-9.

4. Álvarez-Félix JR, Palazuelos-Gaxiola M, Cinco-Sánchez A. Lesión corneal causada por picadura de abeja. Rev Med UAS. 2016;6(1):19-21.

5. Bhalerao SA, Singh P, Rani PK, Rathi V. The sting of a honey bee: an unusual sub 